\title{
ON SWEDISH
}

\section{A N D SCANDINAVIAN \\ HERITA G E}

Aged 31, Professor Axel Key married 20-year-old Selma Charlotta Godenius in 1863. The newly-weds spent their honeymoon touring Central Europe and settled in a large apartment in the Old Town in Stockholm, not far from the shore at the M älar lake where 2 years later the new Karolinska Institute was built with one wing for professor Key's pathological anatomy department. By this time Alfred Nobel had returned temporarily to Stockholm after having spent many years in St. Petersburg. Key, who was member of several distinguished societies in the Swedish capital, built a patriarchal summer residence, Bråvalla, on the outskirts of Stockholm where he arranged social gatherings in old Nordic style. He also worked in very close collaboration with Artur Hazelius to create two monumental Swedish landmarks, the Skansen open-air museum and the Nordiska M useet (Nordic M useum), both established and built over a long period of time on the island of Djurgården in Stockholm. At Skansen, farm yards from various parts of Sweden are displayed including folk life of bygone days. Typical traditions are kept alive and the Swedish heritage in all its forms is manifested. At Bråvalla, in 1888, Key celebrated his silver wedding anniversary and many were the internationally recognised celebrities who visited him here over the years, such as Rudolf Virchow and Theodor Billroth. When the former celebrated his 70th birthday in Berlin, Key reported from the festive event. Himself, Axel Key received a magnificent celebration when in $M$ arch 1897 he retired from the post as Rector for the Karolinska Institute, a position he had held since 1886. 


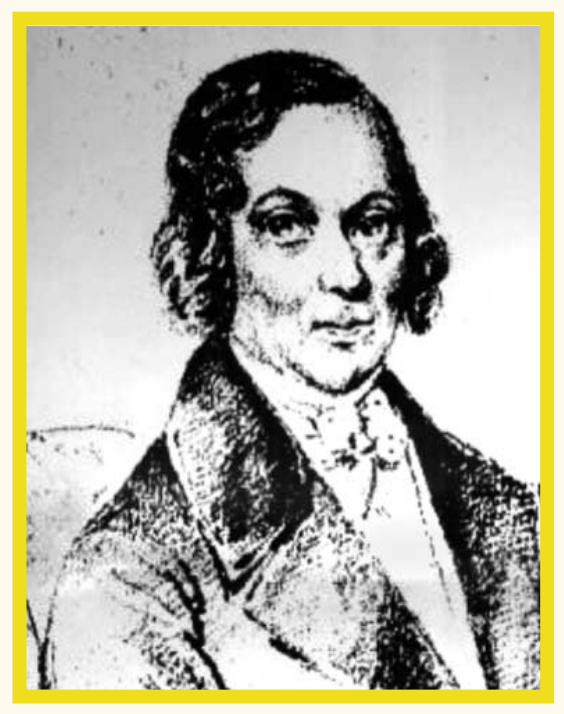

Johannes Samuel Norbin

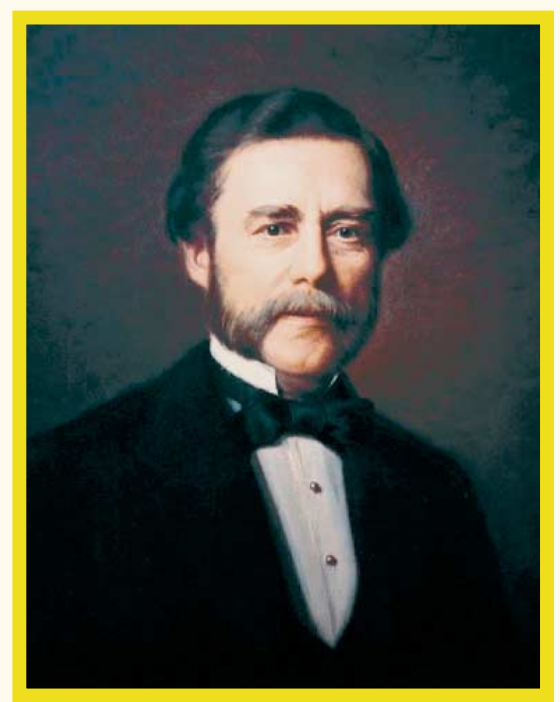

Carl Jakob Rossander
On 3rd August 1863, Axel Key married Selma Charlotta Godenius, daughter of a locally well-known Stockholm wholesaler and foundry proprietor, Samuel Godenius (fig. 47), who had been, since 1852, owner of the porcelain factory Gustafsberg on the outskirts of Stockholm, and his wife $\mathrm{M}$ aria Charlotta, born N orbin (fig. 48). Sel ma's mother M aria Charlotta was the daughter of J ohannes Samuel N orbin (fig. 45), a Stockholm City Councillor.

At the time of their marriage Selma Charlotta had not yet reached her 20th birthday. She had, how ever, travelled a great deal. Her sister, Emmy Godenius, was 4 years older, and engaged to Carl R ossander (fig. 46), whom she married in 1861. Q uite possibly, in the autumn of 1861, Carl R ossander introduced his friend Axel Key to Selma Charlotta. R ossander later became Professor of Surgery (and O phthalmology) at the Karolinska Institute.

In 1860, Carl Rossander made a study trip to Germany, France, Switzerland and Italy. Samuel Godenius had arranged for Selma to accompany Dr. R ossander in order to broaden the girl's view of the world. On that journey, while in Berne, the then 17-year-old was quite charmed when introduced to M onsieur H enri Dor, a 25-year-old Swiss doctor, who later became Professor of 0 phthalmology at the University in Berne.
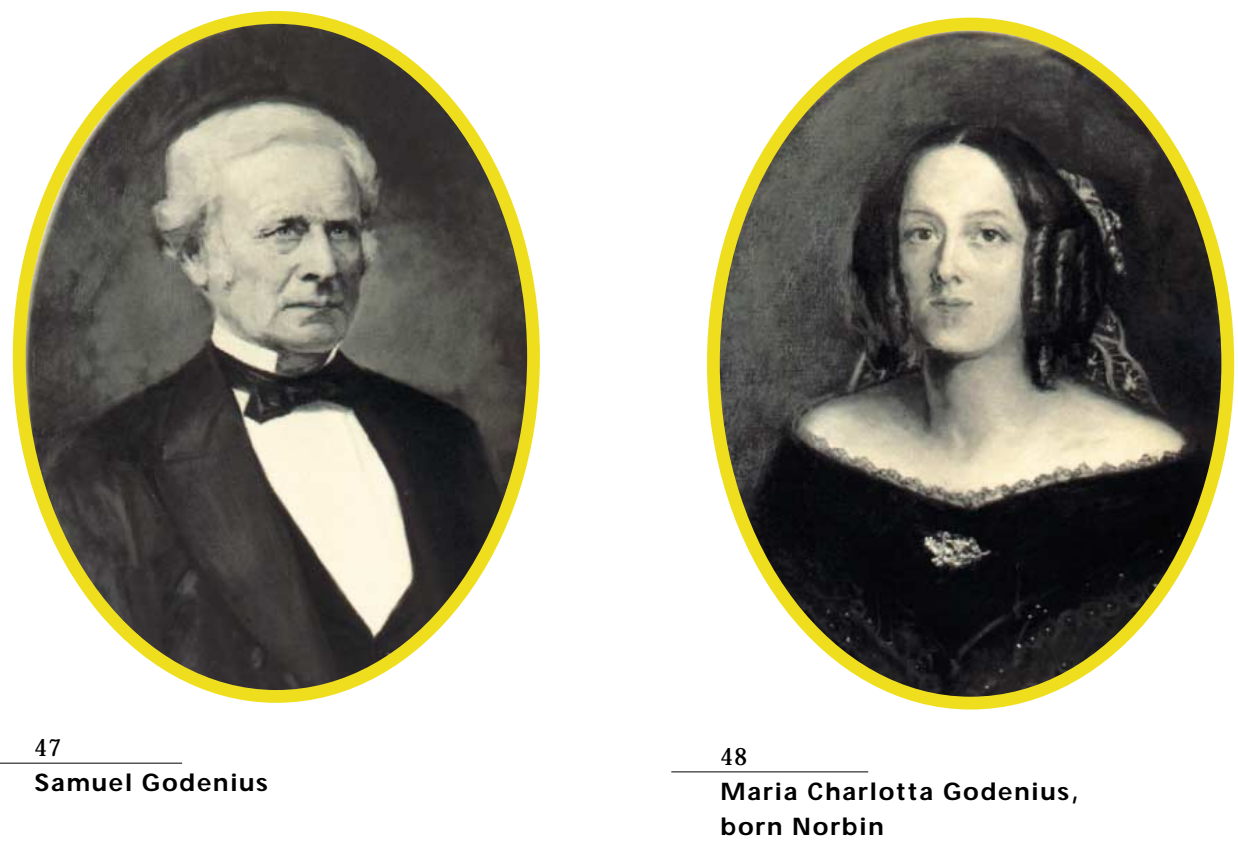
The guests who were invited to the wedding ceremony when Selma was married to Professor A xel Key were brought to Gustafsberg, from an assembly at the statue of K ing G ustavus III in central Stockholm, by paddle steamer (fig. 49).

The newlyweds (fig. 50) spent their honeymoon touring Central Europe. On their way to Paris, Westphalia in particular was enchanting. At this time the railway network in Sweden as well as in Central Europe was fairly rudimentary and long distances were covered by carriage and four, with changes of coachman and horses at shelters along the road. A fter a stay in Paris, Selma and Axel continued their journey through France to Rome and $\mathrm{N}$ aples and then by steamboat to $\mathrm{M}$ arseilles.

Upon their return to Stockholm, the couple settled in an apartment in the O Id Town at $\mathrm{M}$ älar square, i.e. on the island harbouring the R oyal $\mathrm{C}$ astle in the centre of Stockholm. The property still remains (M älartorget 13). It was planned by the well-regarded Stockholm architect J ohan Fredrik $\AA$ bom, who also designed buildings such as the Dramaten theatre, the $\mathrm{H}$ asselbacken and Berns auditoriums and the R oyal Academy of $\mathrm{M}$ usic where the first $\mathrm{N}$ obel Prize ceremonies took place in 1901. The young Key family occupied the fourth floor of the property, which commanded a view over $L$ ake $M$ älaren and the shore on the Kungsholmen island where the 'new' Karolinska Institute was built in the 1860s (fig. 43).

In the mid-1860s Stockholm was an insanitary and overcrowded city with a population of 100,000 , built on thirteen islands ${ }^{14}$ mostly connected via pontoon bridges. The cobbled streets were dirty, and often flooded. Fresh water supplies were scarce or nonexistent and the town lacked a proper sewage system. Poverty was widespread and many inhabitants had difficulty in finding a sufficiently warm place to sleep at night during the long cold winter. Street lighting consisted of rape-oil lamps and most people did not venture out after dark. Infant mortality was high and affected the affluent as well as the poor.

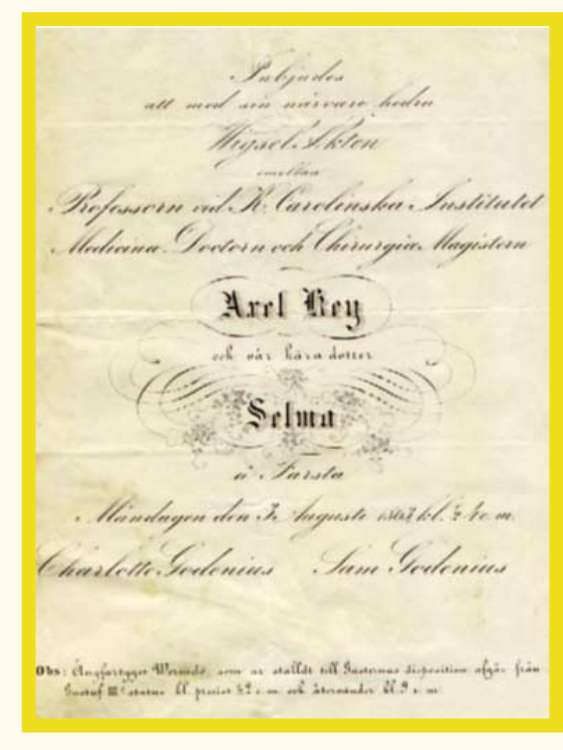

49

Invitation to attend the wedding ceremony on 3rd August 1863

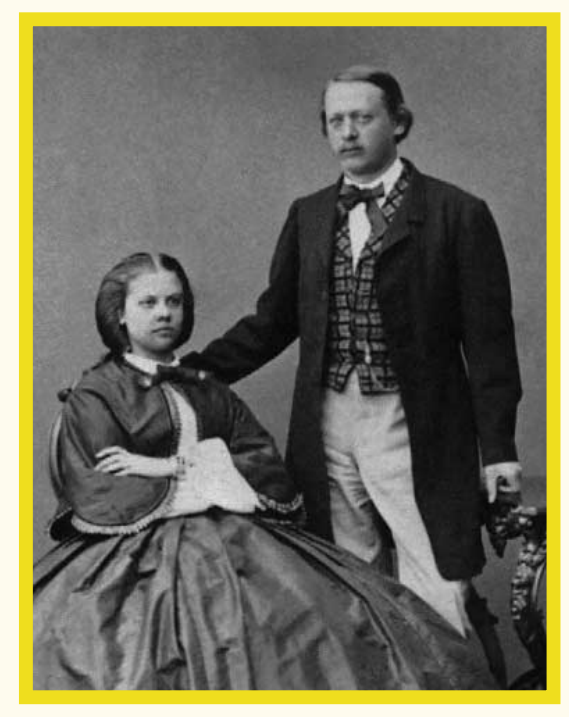

50

Newly wedded Selma and Axel Key

${ }^{14}$ 'H olmar' in pluralis; 'holmen' in singularis. Compare: Stockholm, Kungsholmen, Blasieholmen, Riddarholmen, $\mathrm{H}$ eleneholm, etc. 


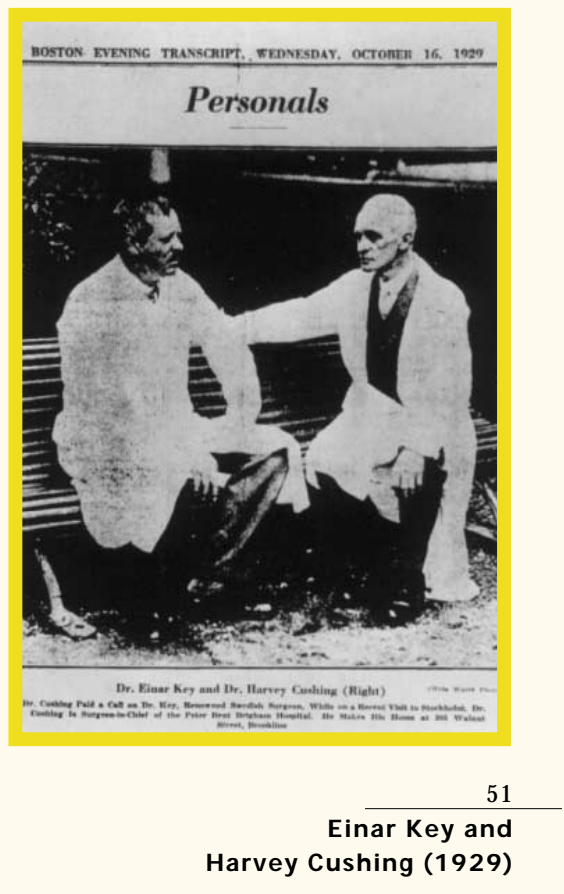

Selma and Axel (fig. 50) were to have 8 children, of whom only 4 survived to adulthood (fig. 31). Their daughter $M$ aria lived for less than a year and died in 1870, their son Thorsten died aged only two in 1876, their daughter Ebba died aged 10, also in 1876, and A stri was 12 when she died in J une 1900 from a ruptured retrocaecal appendicitis causing acute peritonitis. Their eldest son $\mathrm{H}$ elmer Key becamea publicist, daughter Elise married a surgeon, son of the D ean at the U niversity of Lund, Professor of literature and one of the 18 members of the Sw edish A cademy. Daughter Thyra married a doctor, who became Professor of Pathology at Uppsala University, while the youngest son, Einar, became Professor of Surgery at the Karolinska Institute. H e developed a close friendship with many world-renowned surgeons of the day, such as Ferdinand Sauerbruch, Fedor K rause and US pioneer neurosurgeon $\mathrm{H}$ arvey Cushing (fig. 51).

\section{THE IDUN SOCIETY}

In 1862, Axel Key and five other prominent young men decided to found a society which was named 'Idun' (fig. 52). This society, where Key had his numbered chair for almost 40 years, still flourishes today with Professor Lars Erik Böttiger of the Karolinska $\mathrm{H}$ ospital as Secretary.

On 22nd N ovember 1862, the six founders met at Hotel Fenix in Stockholm and established 'Idun' in order to 'bring about a widened personal acquaintance between Stockholm-settled men who have demonstrated an active interest with regard to science, literature and/or art'.

The other initiators of the society were $\mathrm{H}$ arald $\mathrm{W}$ ieselgren, a prominent librarian who served as Secretary for 'Idun' till his death in 1906, explorer A dolf Erik N ordenskiöld, landscape painter Edward Bergh, folklore painter J ohan Fredrik (Janne) H öckert, and the composer Ivar H allström, who was devoted to Old Norse music and who was to compose the opera 'The Vikings' in 1877.

In December 1879, Key gave an impassioned speech to 'Idun' in honour of its member, Adolf Erik Nordenskiöld, who was then back home in Stockholm after a global journey during which he had discovered the $\mathrm{N}$ ortheast Passage in 1878/1879. The G ala Banquet on 28th A pril 1880, i.e. 4 days after $\mathrm{N}$ ordenskiöld's jubilant return to Stockholm, was given at the R oyal A cademy of Science and attended by King $\mathrm{O}$ scar II. The menu design, by 
artist $\mathrm{C}$ arl L arsson, depicting the goddess of victory, $\mathrm{N}$ ike, with a helmet and the sign SCIEN TIA, and an owl, the symbol for wisdom, listed: Tortue claire à la R usse, Timbales Impériales, Turbot à la H ollandaise, Filet de boeuf à la Française, Filets de gibier à l'Esencial et sauce Périgord, Pyramide de homards aux huitres, Petits poulets rôtis et salades, A sperges nouvelles au beurre foutté, Pouding à la V ésuvienne, Glaces assorties, Fromages and Dessert. The list of accompanying beverages included: Château Palmer, Sherry, Château Yquem, Champagne, Chateau Beychevelle, M ontrachet, Punch à la R omaine, Château Lafite, $M$ arcobrunner, $M$ adeira and vintage Port. O ne week after the dinner, on 5th $M$ ay 1880, Key gave a jubilant speech in honour of Nordenskiöld at an 'Idun' gala celebration at R estaurant $\mathrm{H}$ asselbacken on D jurgården. The cover of the nine-course gala dinner menu was again created by the famous Swedish artist Carl Larsson. It depicted a statuette of $\mathrm{N}$ ordenskiöld being offered champagne and fruits by Idun (Goddess of health, wife of Brage, who kept apples in her basket for eternal youth according to mythology) in O Id N orse attire with polar bears and a seal in a bowl underneath and a verse by poet Frans $M$ ichael Franzén inviting the guests to 'drink and stay happy since on this planet earth people don't seem to enjoy life often enough'. The menu began with chicken mousse served with Cos d'Estournel 1874, then petit patées served with sherry, followed by $\mathrm{H}$ almstad salmon with spinach and eggs served with East Indian madeira, and, after that filet mignon with vegetables, served with champagne. The fifth course was cold Bayonne ham accompanied by Clos de Vougeot; then followed chicken salad served with a glass of Château $M$ alescot, vintage 1864. The next course, cold fresh asparagus, was served with R auenthaler Berg \& Selters spring water. O range pudding came with sherry and finally ice-cream was served with vintage port wine. For the guests and connoisseurs who by then were not totally sated or intoxicated, there was an additional serving of cheese and dessert.

For the celebrated arctic explorer, who had lived for years away from a more sophisticated way of life, it must have been quite arduous from a digestive point of view! The menus from the Banquets at the R oyal A cademy of Science and at the Idun certainly testify that only the best was considered good enough for the great arctic explorer. O nce, while in $\mathrm{N}$ apoli in early D ecember 1872, Key had read in an Italian newspaper the alarming news that $\mathrm{N}$ ordenskiöld had not been heard of for a long time and that it was feared that he had succumbed in the A rctic 0 cean.

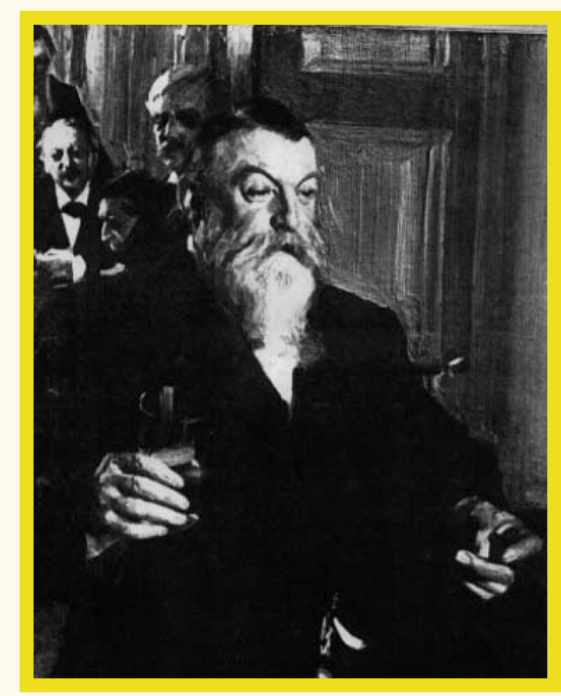

52

'A Toast in the Idun Society.' Painting by artist Anders Zorn (1892). From left to right Hans Hildebrand (archeologist, member of Swedish Academy), Axel Key, Carl Fredric Waern (industrialist, civil servant, politician), Adolf Nordenskiöld, in the foreground Harald Wieselgren who has just proposed the toast 

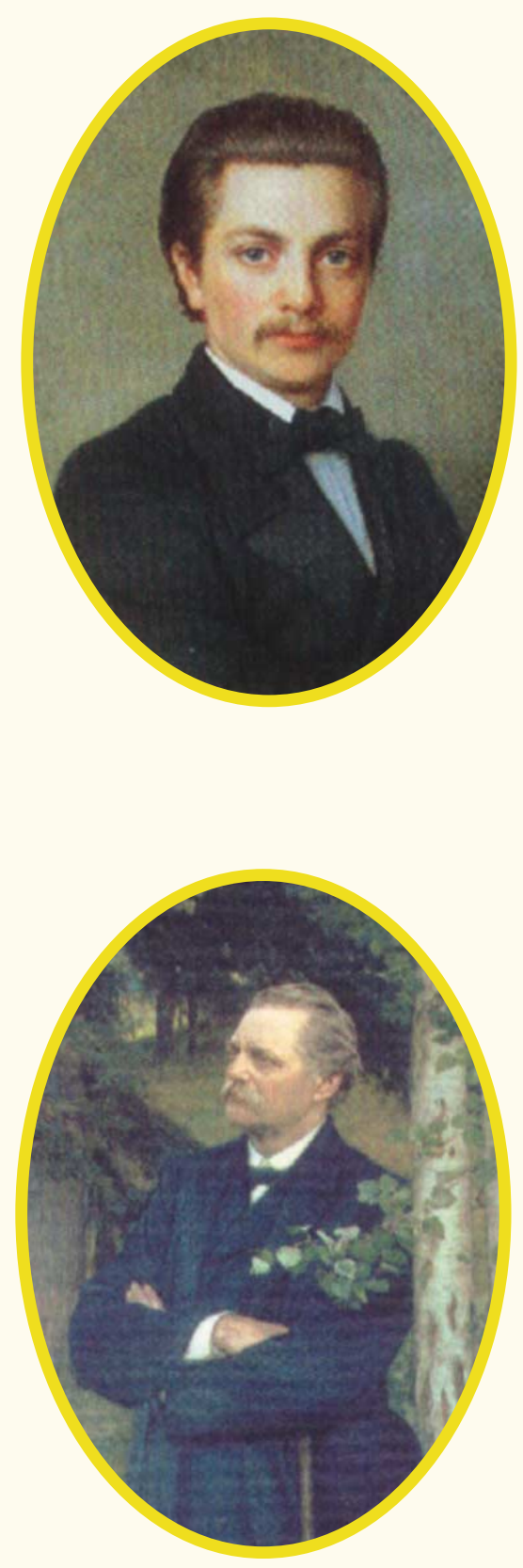

Above in the 1850s; below in the 1880s
KEY'S COLLABORATION WITH ARTUR HAZELIUS

A rtur $\mathrm{H}$ azelius was a doctor of philosophy, who had an abiding interest in $\mathrm{N}$ ordic and Swedish peasant culture and ancient history. As a student he had been on a journey through the Sw edish landscape Dalarna (D alecarlia), where he noticed dramatic changes brought about by industrialism. These observations made him realise the need to start saving something of the old, traditional farming culture for future generations. In D alecarlia, $\mathrm{H}$ azelius acquired as his first objects some folk costumes. At an early stage his collections, which highlighted the history of the Swedish people, captured Key's interest. In 1873, with strong support from Key, H azelius founded a new small-scale museum, the Scandinavian-ethnographical collection at Q ueen Street N o 71A in central Stockholm. The goal was to present a broad cultural-historical outline of the $\mathrm{N}$ ordic countries using a new exhibition technique, which quickly became a great success: a diorama placing full-scale dummies in folk costumes in authentic settings. $\mathrm{H}$ azelius and $\mathrm{K}$ ey won special acknow ledgment at the World Exhibition in Paris 1878 where the museum was acclaimed worldwide. In his devotion to O Id N orse tradition $\mathrm{H}$ azelius (fig. 53) had a close ally in Key.

A practical disposition, an eyefor detail and his many contacts with leading decision makers made $\mathrm{A}$ xel Key crucial to $\mathrm{H}$ azelius in his endeavours to establish an enlarged $M$ useum built on the island of Djurgården in central Stockholm. In 1880, their museum was renamed the N ordic M useum. O ver and above all his other obligations K ey, from 1894 till his death, chaired the Board of the N ordic M useum, which in its final form, as it stands today, was solemnly inaugurated in 1907 (fig. 54).

The central area of the museum, the $\mathrm{G}$ reat $\mathrm{H}$ all, was created for national mass celebrations. At Skansen (see below) great festivals were celebrated in honour of old hero kings. Wars and battles were demonstrated through playful tableaux vivants. This Swedish nationalism resulted in a shared sense of values, a feeling of fellow ship and coherence amongst the Sw edish people.

$\mathrm{H}$ azelius and $\mathrm{Axel} \mathrm{K}$ ey also shared an interest in the roots of different Swedish and $\mathrm{N}$ ordic dialects, grammatical correctness and the cultivation of linguistic purity. H azelius collected objects illustrative of the historical evolution of the Swedish nation, and created an outdoor exhibition with scenes of old folklore and various aspects of village life from the past. In the mid-1870s, K ey was engaged in discussions with the Stockholm city plan- 


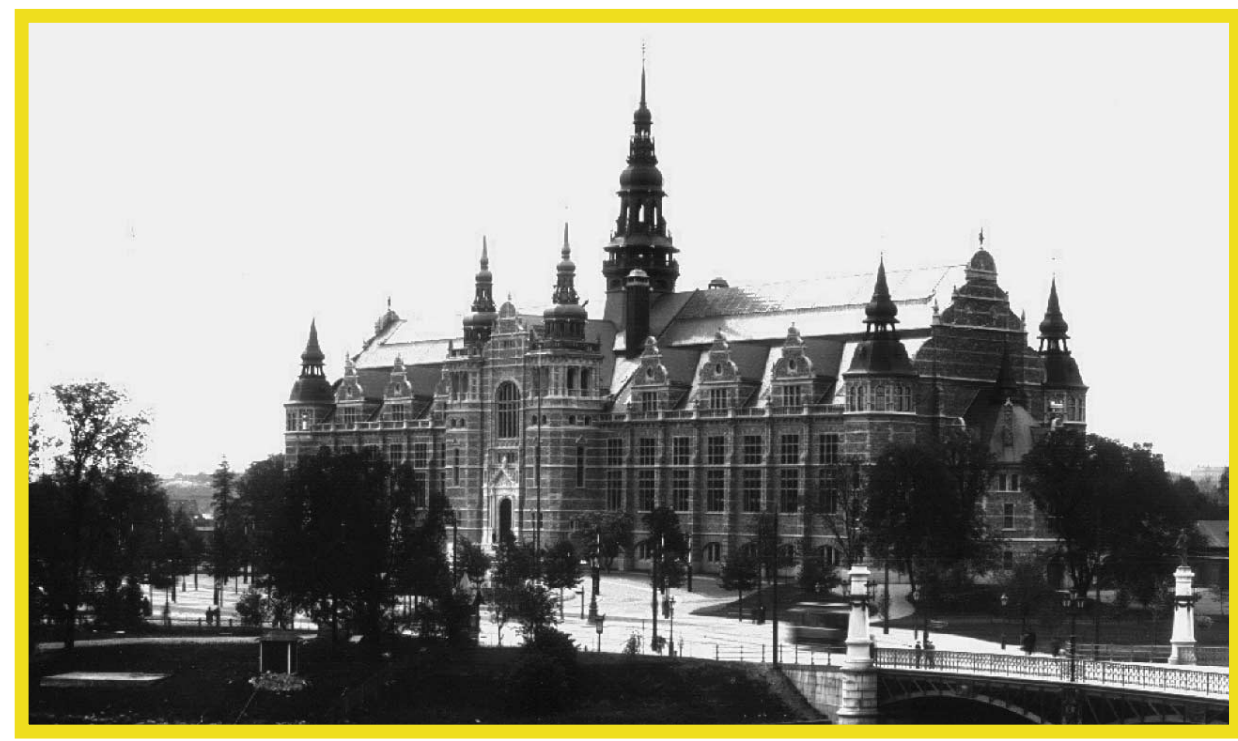

54

The Nordic M useum

ners to purchase a large area on the island of D jurgården for the establishment of a public zoological garden. In 1891, the extensive open-air museum, Skansen, was inaugurated in Stockholm in the Djurgården district, near the centre of the city. It was the world's first open-air museum in the middle of a large city where visitors can study the nation's flora as well as farmsteads (fig. 55) with the traditional livestock and breeds with enclosures for wild animals such as the elk, wolf, bear, lynx and seal. Skansen is open all year round and offers the visitor experiences in time and settings from past generations, with town quarters, farmsteads and homes meticulously moved and rebuilt as in olden times with living people dressed in old costumes and using crafts from by-gone times. M ost festivals in Stockholm are celebrated at Skansen, where there are autumn and winter markets, concerts and a variety of folklore displays and folk dance performances. $M$ any attractions, including a special children's zoo and children's circus, make it a paradise for youngsters, just as $\mathrm{H}$ azelius and Key intended when they planned this national outdoor museum.

Both $\mathrm{H}$ azelius and Key were deeply involved in the education of the Swedish people and the promotion of this movement in a spirit of patriotism. They set out to nationalise the programme with cultural object lessons and the arrangement of Skansen festivals, which enhanced the traditions of the Swedish people. With this form of 'ennobled public entertainment' $\mathrm{H}$ azelius and $\mathrm{K}$ ey set out to safeguard the morality and disposition of the people. To this end the central theme worked well - the creation of a common concept of Sweden. H azelius declared: 'It is a matter of creating tradi-
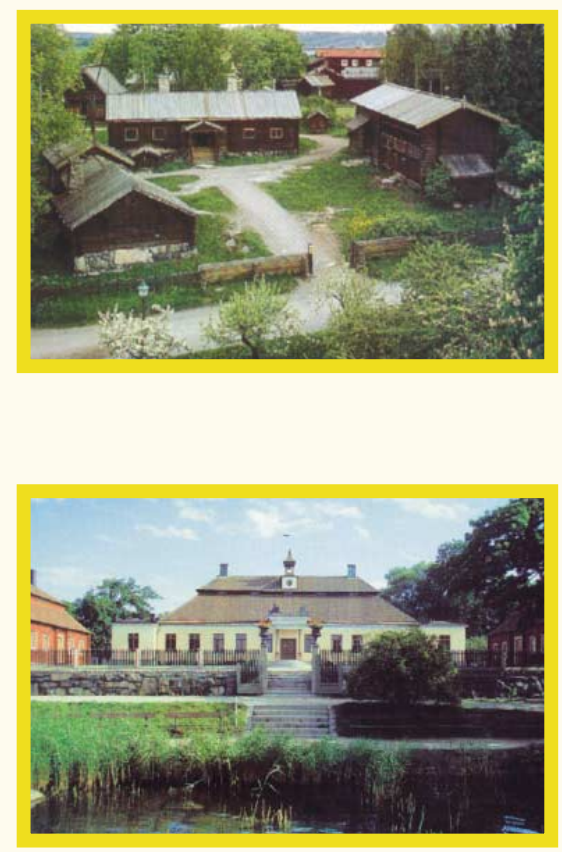

55

The Älvros Farmstead from northern Sweden (above) and Skogaholm Manor (below) rebuilt at Skansen open-air museum in central Stockholm 
tions which will never be abandoned' and in this he has so far been proved right. The annual celebration of St Lucia on 13th December and of the Sw edish Flag on 6th J une are festival days in the true spirit of Sw edish patriotism.

As an adult, Key's daughter Thyra reminisced about the time her father was engaged in scientific projects, political matters and the establishment of the $\mathrm{N}$ ordic $\mathrm{M}$ useum and Skansen in collaboration with Artur H azelius:

'Papa used to work late at night. A formal dinner was only given at home when foreigners came to town. When Virchow made his last visit to us, I was an adult. $\mathrm{O} n$ that occasion he gave a speech, which gave me my first indication of the degree of renown which was attached to Papa's name. This was expanded and confirmed by the speech which Virchow gave in Papa's honour at the $\mathrm{N}$ atural Sciences $\mathrm{C}$ ongress ( $\mathrm{N}$ aturwissenschaftlicher Kongress) in M unich in 1899 and by the spontaneous acclaim which was then accorded him.'

$\mathrm{O}$ ver many years, $\mathrm{H}$ azelius and Key collaborated so closely that $\mathrm{H}$ azelius had his own latchkey to Key's home so as to be able to visit even at night.

\section{AXEL KEY - A NEW - GEATISH SCA N D I N A V I S T}

O Id N orse inhabitants on the mainland of Sw eden are called Geats. Axel Key had all of the characteristics typical of a so-called new-Geatish Scandinavian. He was a true patriot, a superb educationalist, politically liberal, engaged in matters of hygiene, promoting a generally increased standard of living for the Swedish population, and a nature-lover with the flora of Lapland as his speciality. With these characteristics he certainly offered all possible support for the foundation of a N ordic M useum in Stockholm. He was also an advocate for physical training and favoured a strong Swedish military defence based on compulsory military service for all young men.

$\mathrm{N}$ ordenskiöld and Key were strong-principled men who believed in reforms which would lead to general democracy and a change in the classstructure. Both refrained from accepting decorations from the Swedish R oyal family although Key accepted a royal medal in 1854. N ordenskiöld accepted the G rand Cross of the N orth Star O rder when, in 1880, taken by surprise upon his return on $\mathrm{M} / \mathrm{S}$ Vega after having discovered the $\mathrm{N}$ ortheast 
passage, was met by jubilant crowds and the Swedish King, who decorated him just as he landed at the Logård quay in Central Stockholm. The popular explorer simply could not refuse in front of everyone assembled.

In the years 1869 to 1870 , with the help of his father-in-law, Axel Key was able to build a special house, Bråvalla, at the Farsta bay just outside Stockholm. 'Villa Bråvalla' became an example of a patriarchal residence in the style prevailing in the 1870s - a modified Suisse chalet (fig. 56).

With Key's strong feelings for the $\mathrm{O}$ Id $\mathrm{N}$ orse Saga, Bråvalla was built as a castle-like, timbered, airy cottage in two storeys meant for relaxation as well as work or social gatherings. It was designed by the architect J ohan Erik Söderlund, who had planned the new Karolinska Institute including Key's Department of Pathological A natomy at Craftsmen Street in Central Stockholm. The site for Villa Bråvalla was chosen because K ey's father-inlaw owned the Porcelain Factory Gustafsberg, to which all the land around the Farsta bay belonged. Villa Bråvalla was provided with many O Id N orse features and was built in large grounds, boasting rare plant species and wild flowers. The name Bråvalla referred to the legend of the Battle at Bråvalla wherein D anish and Sw edish Vikings were said to have run amok in the distant past, a legend that spawned the need for union instead of disruption and killing amongst the $\mathrm{N}$ ordic peoples. Close co-operation between the $\mathrm{N}$ ordic countries in various spheres, and particularly the scientific realm, was very close to Axel Key's heart. $\mathrm{H}$ is intimate friends often jocularly referred to Axel Key, whose most cherished desire was N ordic Unity, as the Bråvalla Ruler.

At weekends, Key loved to invite his many friends to visit Bråvalla Battlefield. In his letters of invitation, gentlemen were asked to come in full parade dress. This was, how ever, not to be taken literally, as the invitation notes to Bråvalla or to his home at the M älar Square in Stockholm were in jest. Key owned a Viking ship that evoked a traditional picture, and in the garden at Bråvalla stood a wooden image of Tor - a famous N ordic god.

When the Bråvalla R uler had arrived in the evening on board the paddlesteamer 'Wermdö' from Stockholm or, as from 1871, aboard the steamship 'Gustafsberg I', he took his place on the Viking-type high settee designed by the artist A ugust $M$ almström and carved in oak. O $n$ its high back support, Key had his initials engraved in runic characters with a relief depicting the Viking warrior Sigurd with axe and shield attacking Fafner the D rake, and warrior $\mathrm{O}$ den with spear and shield riding on his eight-legged horse Sleipner. Wooden armchairs richly ornamented with symbols from the Old $\mathrm{N}$ orse Saga stood against the walls of the hall.

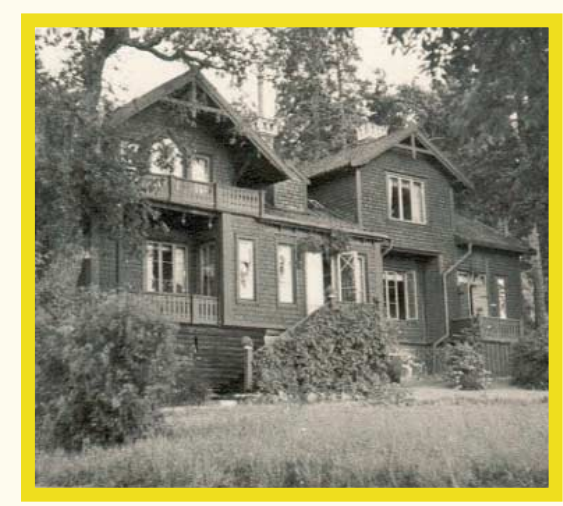

56

Villa Bråvalla built in 1869-1870 


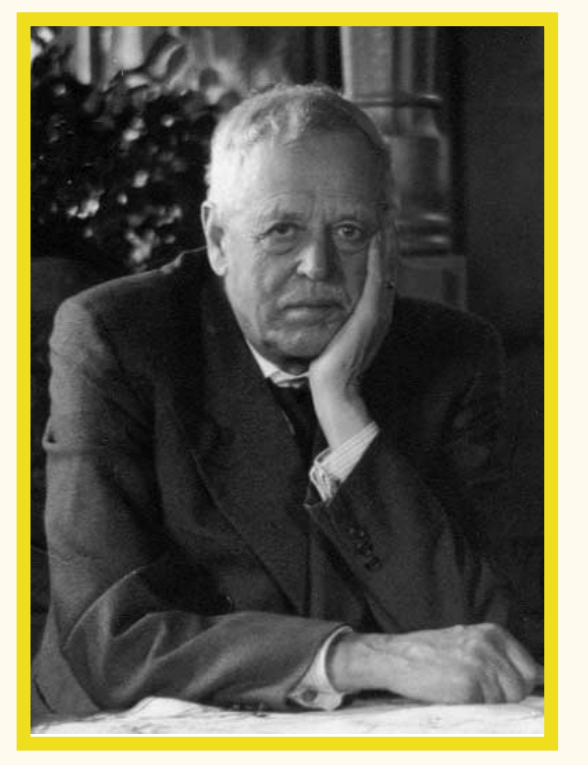

57

Professor Einar Key

(1872-1954)

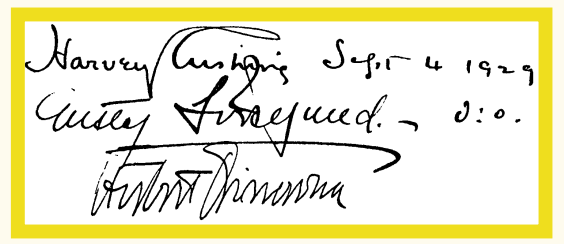

58

From the guestbook at Bråvalla where Einar Key brought his colleagues Harvey Cushing and Herbert Olivecrona on 4th September 1929
When Key was visited in Stockholm during the summer months by friends from Central Europe, he brought them to his cherished Bråvalla. Virchow came and so did Theodor Billroth, who, in mid-A ugust 1874, wrote to Axel Key that 'Es hat mir so gut bei Ihnen gefallen. Das poetische H aus ist mir sehr fest im G edächtnis geblieben.' (It was so nice being with you. I have retained a strong memory of the poetic house.) O $\mathrm{n}$ a much later occasion, on 4th September 1929, Axel Key's son Einar Key (fig. 57) brought a quartet of prominent doctors to Bråvalla: A merican neurosurgeon $\mathrm{H}$ arvey Cushing, who was on a brief visit to Sweden, H erbert O livecrona, surgeon Einar Perman and radiologist G östa Forssell (fig. 58).

\section{' $\mathrm{THE} 17^{\prime}$}

In February 1887, a society was founded in Stockholm by thirteen friends with various social and scientific interests. Within a few years this group was enlarged by four more members and consequently called 'THE 17'. The members of 'THE 17' were all persons who courted liberal views. Each member was assigned a numbered seat and the agenda of the society was to gather together individuals to discuss multidisciplinary matters on a regular basis. O $\mathrm{n}$ 6th February 1888, its member Axel Key delivered a talk: 'A bout statistical examinations on the development of young people during the various stages of their adolescence', with a remark that urban girls precede rural girls by a couple of years in menarche. The members of 'THE 17' (see A ppendix) were all prominent Stockholmers and included sixteen $\mathrm{N}$ ordic learned men and one woman - Sonya Kovalevskaya. 'THE 17' still exists and its 17 members gather biannually in Stockholm. Its present secretary since 1980 - is W ilhelm 0 del berg junior, grandson of Wilhel $m 0$ del berg senior, who married Selma Charlotta K ey's younger sister H ilma Godenius in 1869. 


\section{SILVER WED D IN G}

It seems right to conclude that K ey was a chauvinist. When, on 3rd A ugust 1888, he and his wife cel ebrated their silver wedding anniversary, the invitation to attend as well as the dinner menu were transcribed with an 0 Id N orse script (fig. 59, 60):

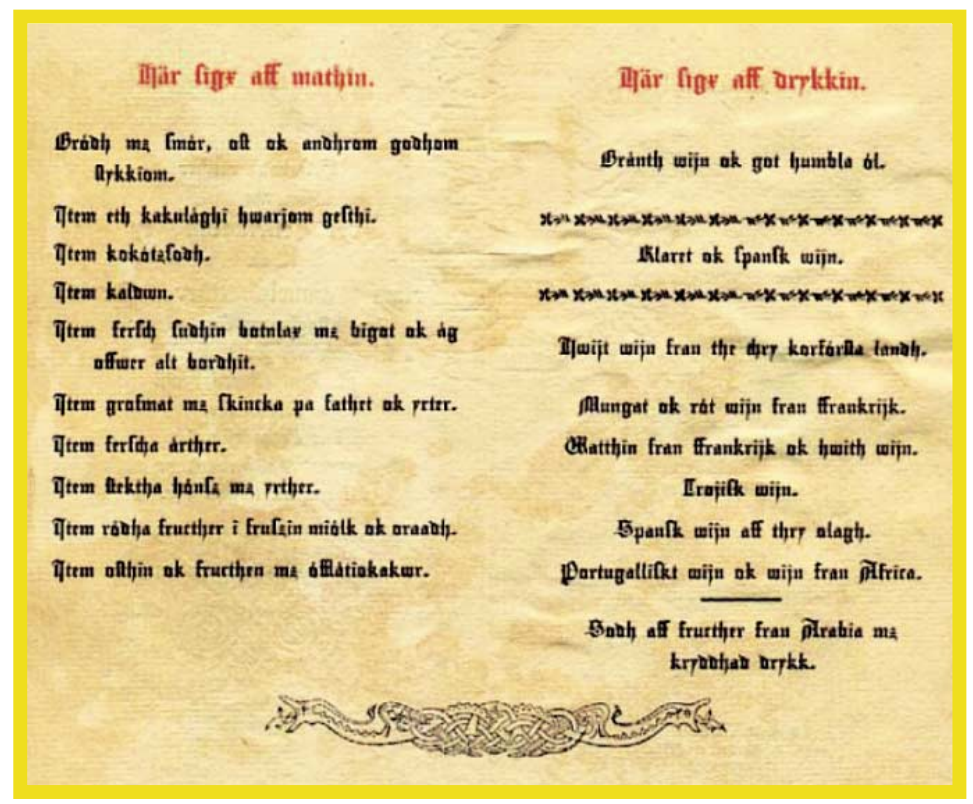

60

Jubilee menu to the left, wines and beer to the right; all in Old Norse

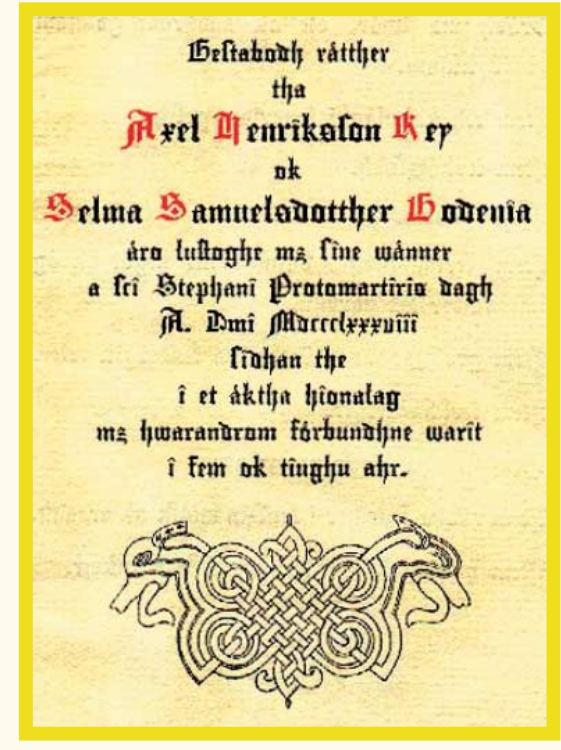

59

Invitation in Old Norse to attend silver wedding anniversary of Axel Key and Selma Godenia 


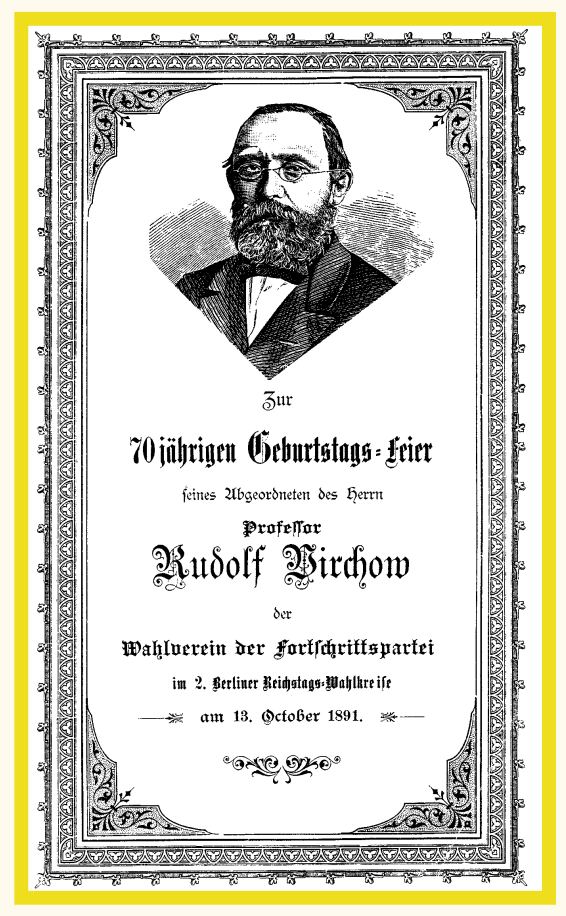

Rudolf Virchow celebrated as a septuagenarian

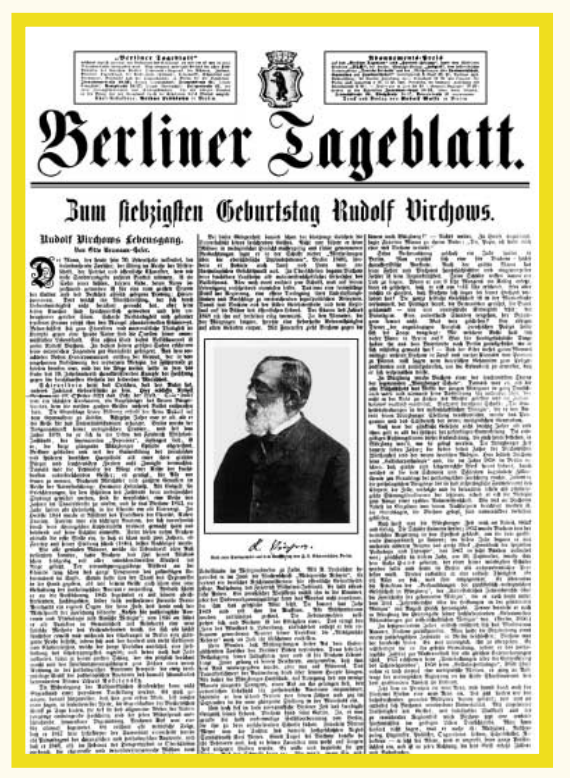

Berliner Tageblatt of 13th October 1891 in honour of Rudolf Virchow
W HEN RUDOLF VIRCHO W

TURNED 70 YEARS O LD

O n 13th O ctober 1891, Rudolf Virchow became a septuagenarian. $\mathrm{H}$ is birthday party was celebrated with pomp and circumstance in Berlin (fig. 61). In Berlin a special issue of the Berliner Tageblatt was published in honour of the $G$ reat Berliner (fig. 62).

Axel Key was there and sent a telegraphic report back to the $\mathrm{N}$ orwegian newspaper D agbladet, in which he tells of 'a jubilant reception' and 'a thunderous applause', especially when one of the speakers had coined the expression 'Bismarck gone, Virchow stays', thereby denoting that the Iron Chancellor had been forced to resign while Virchow - forcing the matter of the resignation - kept his strong position in the German 'Landtag'. Virchow gave a most witty 30 -minute speech. R eciters then read poetry and music was made, followed by a theatre performance, all in honour of the $G$ reat Septuagenarian. The party reached its climax when a bust of the fêted guest crowned with laurel was unveiled.

On the day after the grand party, there was a festive brunch at the Englischen $\mathrm{H}$ ause with 60 specially invited guests followed by a zwangloses Z usammensein in the evening at $\mathrm{H}$ otel K aiserhof (fig. 63).

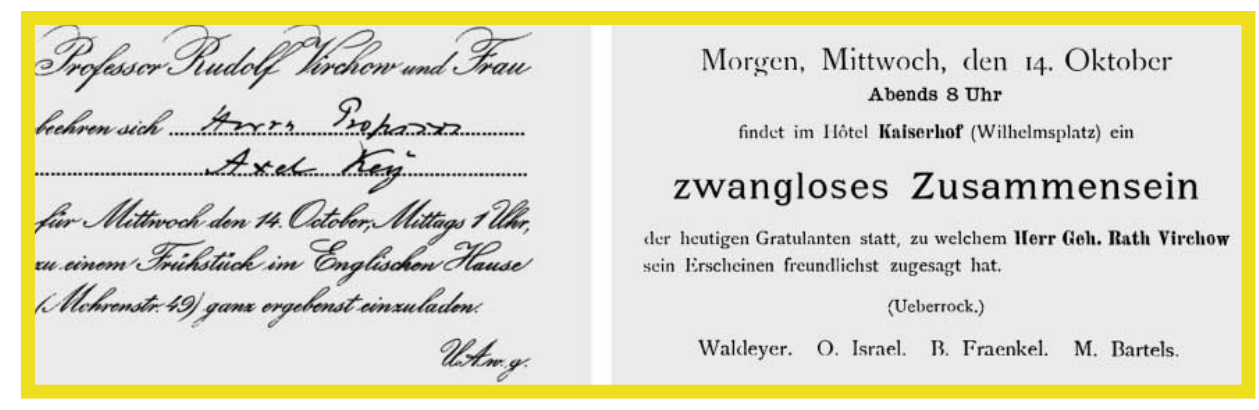

63

Invitation cards to the Englischen Hause brunch at midday and to Hotel Kaiserhof Zusammensein (get-together) in the evening of 14th October (Obs! Waldeyer was the famous proponent of the 'neuron theory') 


\section{K ARO LIN SKA I N STITUTE \\ CELEBRATES AXEL KEY}

On 28th M arch 1897, Key had been professor at the Karolinska Institute for 35 years. In the first decade of this period, it was he who had fought so energetically for equality of status between the Karolinska Institute and the medical faculties of the Universities in Uppsala and Lund. The Karolinska Institute had K ey to thank for the fact that it became considered fully on a par with the other academic medical institutes. $\mathrm{N}$ ot least important for the success of this achievement had been his brave initiative, in 1862, to start M edical A rchives, the medical journal for the Karolinska Institute, which he, in 1869, transformed to $\mathrm{N}$ ordic A rchives for scientific works from Sweden, Denmark, Norway and Finland, and also for its international distribution. During the whole period that Key was its R ector, he was the figurehead for the Karolinska Institute.

The 28th M arch 1897 celebrations took place in the auditorium of the A cademy of Sciences in Stockholm at Kungsbacken (Kingshill) on the large K ungsholmen island. The festivities started at half past one in the afternoon, when all invited guests with accompanying ladies had gathered in the large flow er-decked auditorium and Professor K ey with family members made their entrance. First, a mixture of 'student' singers (senior and junior doctors and medical students) sang ' $V$ årt Land' ( $O$ ur Country) written by the national poet J ohan Ludvig Runeberg.

Then the next Dean upon office, Professor and count Karl M örner, gavea speech. Count M örner emphasized Axel Key's masterly art of expressing his ideas in a lively, logical and captivating way to every kind of forum, his most active participation in teaching scholars and pupils at the Karolinska Institute for more than three decades, his sharp-sighted observations at innumerable autopsies, and notations which he immediately passed on to his students with up-to-date discussions on the subject in question. Professor M örner especially mentioned K ey's importance in solely establishing and organising an effective and adequate teaching system of medicine at the Karolinska Institute in the 1860s and 1870s. He considered Axel Key to be an heir to the legacy of the pioneers who formed the Collegi M edici medical school and the Royal Caroline M edico-Surgical Institute or Karolinska Institute, such as Jöns J acob Berzelius, A nders R etzius and $\mathrm{M}$ agnus $\mathrm{H}$ uss, and emphasized Key's gift in inspiring and encouraging the students at the $K$ arolinska Institute to pursue scientific medical research in general and especially in pathological anatomy and bacteriology. 


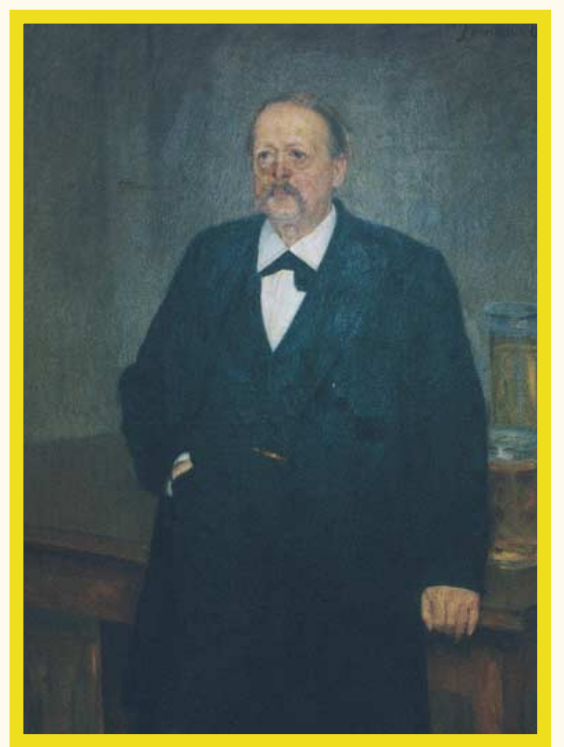

64

Oil painting of Axel Key (1897 by the artist Oscar Björck). At the Department of Clinical Pathology and Cytology of 'Radiumhemmet' at the Karolinska Hospital
Professor M örner also laid stress on Key's ceaseless efforts and self-sacrifice aimed at the promotion of $\mathrm{N}$ ordic medical research, unification of $\mathrm{N}$ ordic medical literature, and prevention of any discord between the Karolinska Institute and the medical faculties at the other two Swedish universities. Following Count M örner's speech, Professor K ey was presented with an illuminated address signed by 43 former and present teachers at the $K$ arolinska Institute, then ' $O$ rfeus sang the tunes of the lute' was sung by the group of 'student' singers.

Then followed a speech by Professor Curt Wallis, who emphasized Key's flexibility and immediate acceptance of the new ideas presented by L ouis Pasteur and Robert Koch. After this speech, a full-length oil painting portrait by the artist $O$ scar Björck was unveiled and presented to Professor Key as a gift from his colleagues, scholars and pupils over the years (fig. 64). A nother song by the assembled choir followed and there was a reading of a poem. $\mathrm{N}$ ext, Professor R obert Tigerstedt, representing the medical Society of Finland, gave his speech emphasizing K ey's gifts in uniting medical education and research in the Scandinavian countries including Finland.

Professor Tigerstedt then walked down from the rostrum to Professor $\mathrm{K}$ ey and continued his speech right in front of him. H e finished by delivering to Key a Festschrift. In 887 pages, it contained 38 scientific papers by $\mathrm{N}$ ordic scientists in medicine which had been collected without Key's knowledge and edited by professors Tigerstedt and Wallis as a separate volume of K ey's own N ordic M edical A rchives. It had been supported financially from private contributions. Interestingly, paper N o. 30 (21 pages with three illustrations) by professors Salomon H enschen and Uppsala surgeon Karl-Gustaf Lennander had the title 'A bout Röntgen rays in service of brain surgery. With Röntgen pictures by Tor Stenbeck.' U pon receiving this gift Professor $K$ ey expressed his gratitude in a few sentences, being 'deeply touched'. A series of congratulatory telegrams were read and the solemn celebration of homage closed with another song by the choir and the reading of a poem written by Professor C arl G ustaf Santesson.

Following his retirement, the Key family moved from the house at $\mathrm{H}$ antverkargatan 3 to a home at nearby Garvaregatan 8 (house later demolished) a few blocks away and still well within walking distance of the Karolinska Institute. At this time $\mathrm{H}$ elmer, Elise and Thyra were all married with their ow $n$ families and only Einar and Atti, aged 10, were still living with their parents. 